\title{
Leichhardt's bust, or how the explorer was rediscovered during the Cold War
}

\author{
Andrew Wright Hurley*
}

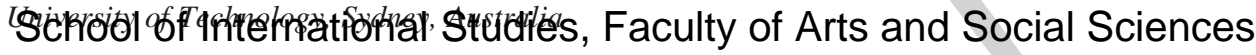

\begin{abstract}
In 1988, the long-lost Ludwig Leichhardt returned to Sydney, not once but three times over, and via an odd Cold War route: his doppelganger great-great-grand nephew, also called Ludwig, travelled from East Germany to participate in a conference; the 'International Friendship League' presented a plaque to the City of Leichhardt; and a bust, for which Ludwig Jr had sat as model, was presented to Australia as a Bicentennial gift. If the bust is an uncanny, inherently unsettling art form, this one challenges us to probe the meanings invested in 'Leichhardt' in Cold War Germany and in Australia. He emerges from the gift exchange as an unstable, transnational figure: one who was never fully owned or disowned, who was subject to competing German national claims, who was ousted from narratives of the Australian nation, but who made a return on cue for the Bicentennial. But this bust figures presence and absence in ways that also ask us to think about what Leichhardt memorialization elided. In particular, its giving both disavowed and emphasized Indigenous experience of colonization at a time when settler Australia anxiously sought to celebrate its Bicentennial and include Indigenous people in doing so.
\end{abstract}

\section{Introduction}

Darrell Lewis has recently asked us in a history of the various searches for the missing explorer, 'where is Dr Leichhardt?' Lewis proposes that we look in a geographical space, central Australia (2013). However, as Thomas (2013) in his review of Lewis's book points out, we might do well to look elsewhere too, into the ways that Leichhardt has been and continues to be remembered so as to serve present-day purposes, as a myth made and remade in the mind, individual and collective. Rather than reaching here to the more familiar - Patrick White and what Priessnitz (1991) has called the 'Vossification' of Leichhardt, or to the reception of Leichhardt in Australian literature, more generally (Martin 2013) - we can turn our attention to two other locations: Canberra and Trebatsch, in regional eastern Germany - to Parliament House and a tiny Ludwig Leichhardt Museum, respectively. Those two locations would seem to have nothing in common other than that they house counterpart copies of an innocuous-seeming bust of Leichhardt, by the German sculptor, Lutz Hähnel (see Figures 1 and 2). I will use this strange doubling of Leichhardt to offer an illustration of the point that Katrina Schlunke recently made in an essay that she and I co-wrote, namely that Leichhardt is far from a settled historical figure, but rather the subject of 'an order of indeterminacy that [has] rendered his life and work available to modes of imaginative interpretation, political score settling and personalised interventions that may never end' (Hurley and Schlunke 2013, 537).

The bust is a comparatively under-researched art form (Brunner 2005, 9). This is partly because it is so ideologically freighted. Busts are often employed in inherently political situations, either as a way of enforcing the commemoration of a leader within a dispersed

*Email: andrew.hurley@uts.edu.au 


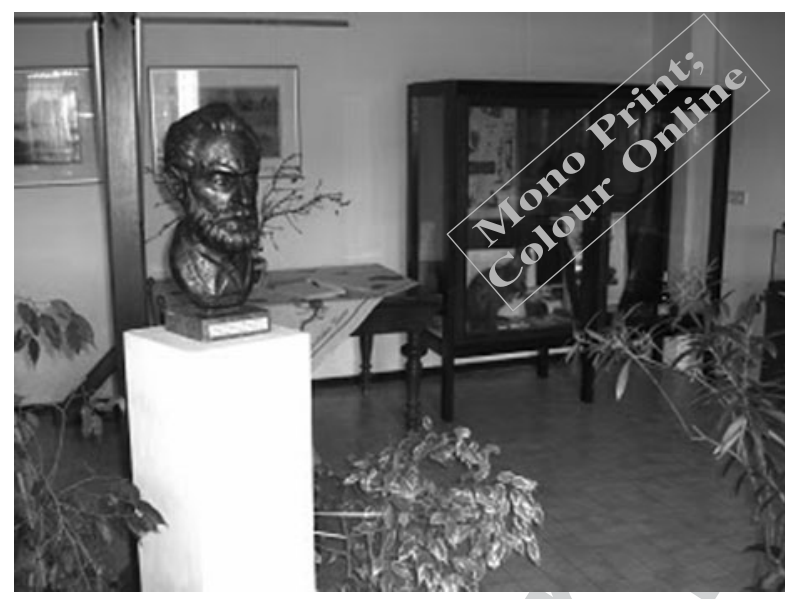

Figure 1. Lutz Hähnel's Leichhardt bust, in situ in Trebatsch, Germany. Picture: Uta von Lonski, reproduced with permission.

empire, or as a symbolic gift from one state to another. In the case of Hähnel's bust, its ideological freight is compounded by the fact that it was the gift of a communist state that no longer exists and, from an Australian perspective, is not greatly mourned. It might not be a bust of Stalin, but it is inscribed with the name of the last East German communist party secretary, Erich Honecker, and it cannot dissociate itself from the German Democratic Republic (GDR), or from the Cold War context of its giving. Aesthetically, that evokes the notion of 'party-minded' socialist realism, according to which Hähnel's bust would not so much be a naturalist portrayal of a real person, but rather a depiction of Leichhardt's 'type', who could then be read within a socialist master narrative (Groys [1992] 2012, 438, see also Clark [2001] 2012). The fact that Leichhardt Sr was not the actual model for the bust would therefore be beside the point from the perspective of socialist realism; it would, in fact, be entirely appropriate. In Australia, Hähnel's bust has,

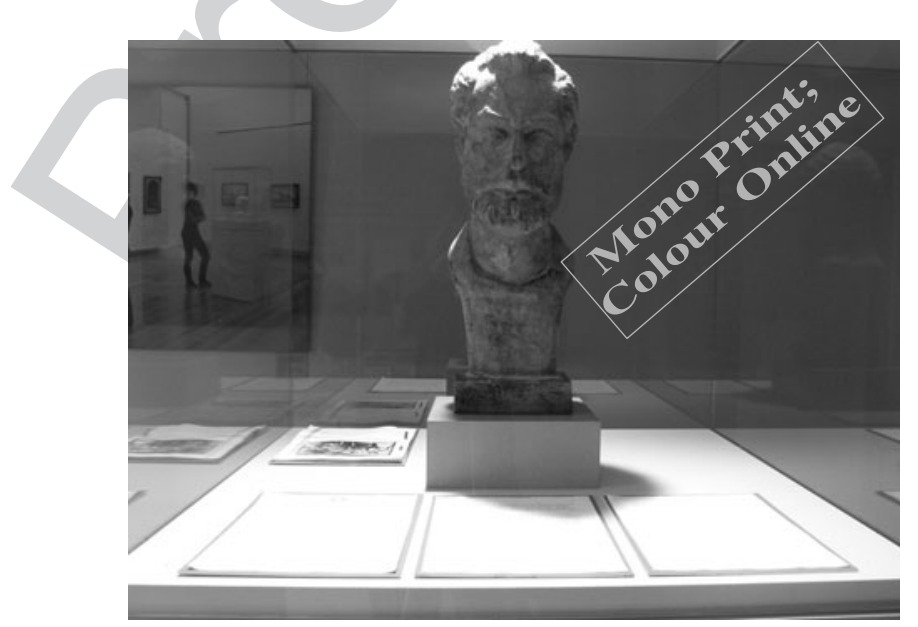

Figure 2. Hähnel's model of the bust, displayed at an exhibition on Leichhardt curated by Heike Hartmann at Schloss Branitz, Cottbus, between 4 May and 31 October 2013. Picture: Heike Hartmann, reproduced with permission. 
until recently, remained largely unseen, the victim of space concerns in the Parliamentary gifts display area and the demise of the GDR as a state needing to be diplomatically accommodated. ${ }^{1}$ Its double in sleepy Trebatsch lives a secluded but altogether more public life. It is unclear whether it still evokes the socialist realist codes within communist-era socialized viewers.

The bust is also an art form associated with the idea of staging personality, and with the outdated idea of 'monumental history' that has decreased in popularity in this country since the second half of the twentieth century (Davison 1988). It is not insignificant that the Parliament House art collection contains only a small number of busts, and most of these were acquired prior to mid-century (Jones, Haynes, and Barron 1993). Not so the GDR, where there was already a nineteenth-century inheritance of reverence for 'great national heroes of spirit', and where monumental busts of figures like Marx and Lenin retained a key place in the country's aesthetic regime. ${ }^{2}$ Recall, for example, the sevenmetre-high bust of Marx erected in Chemnitz (then Karl-Marx-Stadt) in 1971 (see Figure 3). ${ }^{3}$ But the bust is also connected with the notion of the 'great hero' and with ideas of subject-hood that have become discredited in recent times. What is more, busts only represent the 'top half', and in most cases the head. On an orthodox critical reading, this truncates the individual, reducing him or her to a physiognomy or 'character' that inherently devalues the body (Kohl 2005). However, this widespread tendency to

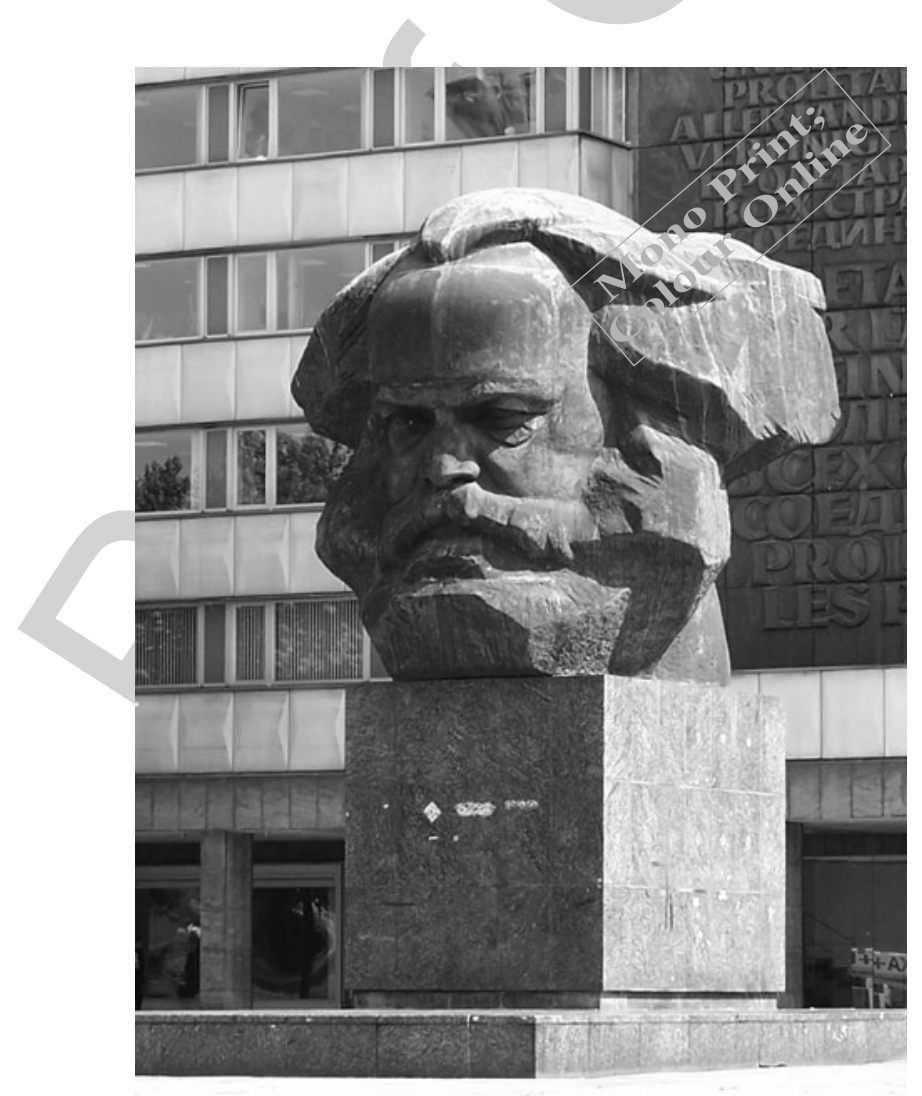

Figure 3. Sculptor Lev Kerbel's Karl Marx bust, Chemnitz. Photographer: Reinhard Höll, permission granted under creative commons. 
disregard the bust also cuts short the uncanny potentialities residing in something which is, after all, a type of severed head.

More recent scholarship suggests that there can be something simultaneously fascinating and disconcerting about the bust. When it is mimetic, we can be fascinated by the likeness, but then irritated by the truncation. Why cut there? What about the body? This approach posits the contemplation of a bust as an act where the recipient can be challenged into an active mode of engagement. (Whereas a two-dimensional portrait can be regarded passively, this scholarship suggests a striking three-dimensional bust begets a conversation [Kohl 2005, 11].) There is also the fact that busts were often modelled from death masks - 'undying faces' - somehow uncannily rendering the dead living again (Benkard 1927). Scholars have also argued that the ostensibly simple commemorative role of the bust is quite uncanny: the object that is 'there' is concerned with remembering a 'great' individual, but that individual is 'not there', nor is his or her body.

Ken Gelder and Jane M. Jacobs have demonstrated in Uncanny Australia that Freud's ([1919] 1999) concept of the 'unfamiliar familiar' can be usefully applied to contemporary Australia, and especially to capture the 'unsettling' 'soliciting' that Indigenous lore performs in the settler Australian context. By contemplating the ways the Indigenous secret/sacred has figured within contemporary discourse, they focus not solely on the feelings of fear that this 'unfamiliar familiar' can and has evoked, but rather advance the idea that the disconcerting-ness of the uncanny can be productive in a political sense. Their overall aim is to 'think through the uncanny implications of being in place and "out of place" at precisely the same time'. (Gelder and Jacobs 1998, 139) Some of these ideas can also be expanded to encompass other cultural presences/ absences, like the one represented by Leichhardt, a figure who, as Schlunke observes, contributed to both the exploration and settlement of Australia, and who was very much invested in 'established race relations and land politics', but was also long regarded as 'strange' and somehow ill 'fits' dominant Australian narratives of self, because he keys 'an alternative history of incipient cultural diversity, intellectual dreaming, and real science' (Hurley and Schlunke 2013, 537-538).

Even if Hähnel's Leichhardt bust might not give rise to feelings of fear, it is in two senses a 'double', another classic hallmark of the uncanny. There is a copy in Trebatsch and one in Canberra. The object also represents Leichhardt Sr through his physical double, Leichhardt Jr, a fact that 'strikes' us as viewers when we see images of both men together, as in two newspaper articles that were published in East Germany and Australia in 1988. At that time, journalists referred to the 'frappierender Ähnlichkeit' (astonishing similarity) and 'striking resemblance' between Ludwig Sr and Ludwig Jr (Corleis 1988; Warren 1988). But the representation through the double also reminds us that, like many other visual representations of Leichhardt $\mathrm{Sr}$, the closer one looks, the further one gets from any 'authentic' representation. ${ }^{4}$ Leichhardt Sr's physical body disappeared without a trace in 1848. Ever since, it has been both nowhere but simultaneously everywhere, as the countless searchers and finders of would-be Leichhardt relics attest (cf. Lewis 2013). Leichhardt's apparition appears to move transnationally too. In 1988, for example, The Australian's journalist suggested that Leichhardt had been 'lost [in Australia] and found [in East Germany]' (Warren 1988). That is not all that is uncanny about Leichhardt. In the East German reading, Leichhardt uneasily evokes the Indigenous experience of the colonial era; here too, he can potentially act as a type of transnational - but obviously 'white' - adjunct to Gelder and Jacob's solicitous, Uncanny Australia. Leichhardt's severed head can cast forth other unsettling matters too: the collection of Indigenous heads during the colonial era, Voss's decapitation by Indigenous people. 


\section{Leichhardt's instability}

The 1988 bust was not a shot out of the blue. It was just the latest East German attempt to functionalize commemoration of this historical figure for present-day ends, to imagine him as part of a useful socialist 'national heritage'. This was not something that the East Germans invented either. Leichhardt had been deployed in a similar yet different way during the National Socialist era too. His surname was used during the 'Aryanization' of place names in his native region of Lusatia. Leichhardt's home village Trebatsch (a Sorbian and hence 'Slavic' name) was duly renamed 'Leichhardt' in December 1937 (Donner 1998, 38; Marx 2003, 25ff.). Leichhardt became a key local figure in the Nazification of the Lusatian 'Heimat', remembered in a 'Leichhardt-Gedenkzimmer' (Leichhardt memorial room) designed by Nazi party member Hermann Kempcke for the Beeskow Heimatmuseum (Marx 2003, 68). His deeds in Australia were also nationally commemorated, for example in Pietzner-Clausen's (1940) book, Der Heimaterde entrissen. Lebensschicksale deutscher Männer.

The Cold War era began inauspiciously for the commemoration of Leichhardt, both in Australia and in Germany. In Australia, Chisholm's (1941) biography Strange New World had advanced a negative image of the explorer that set him apart from a notion of Australian identity that revolved around 'common sense, utility and practical nous'. On this view, 'Leichhardt had offended egregiously against the ethos of mateship and hard-bitten, practical knowledge' (Nicholls 2000, 28-29). He was rendered strange and 'out of place', a quality he has perhaps never entirely shed. Chisholm's work was in key with both a critique of Leichhardt dating back to Mann, Russell and Favenc, and a denigration of Germans that arose from German colonial expansion into Australia's Pacific neighbourhood, and two World Wars (Fischer 2009, 139-140; Schlunke 2014). Leichhardt memorialization in Cold War Germany, on the other hand, was inflected by the earlier 'Nazification' of his memory, and by the fact that his home region of Lusatia was now in the Soviet Zone, what became East Germany in 1949. Geographically, at least, he became 'East German property', but he was tainted property. As Donner points out 'if the National Socialists had commemorated the explorer of Australia then how could one commemorate him in the "antifascist" German Democratic Republic?' (1998, 39). ${ }^{5}$ This was especially the case given that the Slavic Sorbs, whom 'Leichhardt' had been used to suppress, became a 'protected national minority' in the GDR, functioning as a symbolic link with the Soviet Union (Granata 2009, 62). Nevertheless, East German socialists began during the 1950s to construct an image of Leichhardt that could be domestically useful to their national project. ${ }^{6}$ The October 1963 sesquicentennial of Leichhardt's birth catalysed such efforts, but ultimately demonstrated how 'unstable' Leichhardt could be in the face of attempts to push him into a national master narrative. A coalition of local socialists, Leichhardt family members, and antiquarian Heimat enthusiasts - the 'LudwigLeichhardt-Komitee für Cottbus und Frankfurt/Oder' - organized a raft of events including a renaming of a street in Cottbus, lectures and gatherings, and published various articles. Significantly, they interpreted Leichhardt as a man of humble origins, who dedicated himself to the 'lofty development of mankind', who sacrificed his life for science and who could still be a role model for young East Germans (Heinz Haufe, quoted in Marx 2003, 39). ${ }^{7}$ However, this 'socialist' image of Leichhardt encountered resistance. The President of the East German Geographic Society thought that a 'thorough appraisal of Leichhardt's personality' was still needed (Johannes Gellert, quoted in Marx 2003, 40). ${ }^{8}$ Leichhardt's character even became a hot topic when the Komitee tried to persuade the Beeskow local council to rename the school in Trebatsch after him. The council flatly 
declined, effectively considering that Leichhardt was not enough of a 'socialist' for a pedagogic institution to be named after him. He had apparently not said enough by way of political critique, nor enough in favour of Indigenous people (Marx 2003, 46-48). ${ }^{9}$ This rejection restricted the free commemoration of Leichhardt at the time, and contributed to the journalist Heinz Haufe deciding to write a full biography that might answer some of Leichhardt's hard-line socialist critics. ${ }^{10}$

If Leichhardt was an 'unstable' signifier within the domestic socialist frame, then he also began to figure in transnational ways in the post-war era. Twenty-first-century scholarship has stressed the transnational circulations that Leichhardt inaugurated at earlier times, and post-war activities should be seen within that tradition (Nicholls 2012, see also Schlunke 2014). The post-war iteration involved a three-cornered constellation between East Germany, West Germany and Australia. At this time, the 'Hallstein Doctrine' prevented formal recognition of the 'other' Germany by the West German state, and by other western countries, including Australia (Monteath 2008). This was understandably a sore point for the GDR. In this context, Leichhardt was essentially a site at which the East German state might seek some de facto legitimation, or at least raise itself in the estimation of the non-socialist world. However, in the process, Leichhardt began to exceed the polarized Cold War setting. The 1963 sesquicentennial and its aftereffects catalysed some transnational circulation within Leichhardt commemoration, and Leichhardt beckoned as a harbinger of integration, despite the Cold War garb he wore.

How did this work? In the lead up to the sesquicentennial, the communist State and individual East German Leichhardt enthusiasts on the Komitee sought out 'Leichhardt Friends' in West Germany and Australia. In Germany, the dispersed Leichhardt family divided by the Iron Curtain - represented one axis of connection. Some of the family lived in what had become West Germany, and they were invited to join in the celebrations in Cottbus and Trebatsch. The State was interested in their invitation for two reasons. First, the western family's involvement would offer an opportunity to canvas whole-ofGermany research cooperation about Leichhardt that would reflect well on the GDR. Second, it would yield the chance to 'discuss' with West Germans the recent East German elections (Heinz Haufe, quoted in Marx 2003, 42). Favourable attention could also be garnered via an Australian detour. The Komitee won over West German family members to sign a joint communiqué greeting 'the numerous Australian students of Leichhardt'. This communique, which was published in The Australian Geographer, made a show of thanking 'our friends on the 5th continent' for their interest in East German activities, and expressed 'profound pleasure' at Australian-German 'common concern' for Leichhardt, as well as an earnest 'hope that the future will bring you into closer touch with us' (Leichhardt et al. 1963). The letter was pan-German but sent as an address of greeting from East Germany, and it spoke a desire on the part of the East German state for proper international recognition. ${ }^{11}$ But the letter also voiced the hopes of individual Leichhardt enthusiasts about thickening transborder ties in a common area of interest. The Komitee had other more underground reasons for inviting West German guests too; the guests' status as westerners could be used to leverage more funding from the State for the proposed celebrations, since they would make the celebrations into a showcase event (Grosse-Wolf, quoted in Marx 2003, 44). Last but not least, inviting them would also offer a rare opportunity for the members of the Leichhardt family, sundered as they were by the Iron Curtain, to meet up in 'Leichhardt Land'. In other words, individual East Germans were able to use the State's anxieties about its appearance in the non-socialist West concerns caused by the official non-recognition of the East German state outside the Soviet bloc and exacerbated by the construction of the Berlin Wall in 1961 - to advance their 
own private interests. Haufe did something similar in order to lobby the State to finally publish his biography of Leichhardt. ${ }^{12}$

What foreign affairs dividends did the sesquicentennial activities yield? One of the West German Leichhardt family members was reported as congratulating the East German State on its sesquicentennial efforts, which indicated that the investment might have paid off: 'my expectations were thoroughly exceeded [... ] I will always be happy to come to visit you all in the GDR' (Lieselotte Leichhardt, quoted in Marx 2003, 54). ${ }^{13}$ In Australia, however, the result was unclear. This was because of the parallel claims on Leichhardt by the two German states. Defeat and the Cold War had created an anomalous situation where two German states staked out separate versions of a national heritage that could serve their own purposes. The East Germans did not have sole rights to the nineteenth-century explorer, who might have been born in and received much of his training in what became East Germany, but who also attended University in Göttingen, which was in West Germany. ${ }^{14}$ Moreover, he was, as his harder-line socialist critics recognized, not a protosocialist as such. The West German state was therefore justified in coming in on the act during the 1963 sesquicentennial, making the most of the fact that Leichhardt was well known in Australia and that it, rather than East Germany, had an embassy here, as well as a growing cultural outreach programme under the auspices of the Goethe Society (now called the Goethe Institut). Leichhardt duly became a little-known front in what David Caute calls the 'cultural Cold War' (Caute 2003). The West German embassy in Canberra hosted an exhibition of material Leichhardtiana from the Australian National Library, as well as a Goethe Society function, at which the Australian scholar Marcel Aurousseau gave an address on Leichhardt (Aurousseau 1964). This event must have had more purchase on Australian Leichhardt enthusiasts, relatively few in number though they were during the 1960s, than a letter of greeting and communique from the East, or one of Haufe's English-language articles on Leichhardt, published in the internationally distributed DDR Revue. ${ }^{15}$ These competing German national claims on Leichhardt would come to a head during the 1988 celebrations, further undermining the GDR's cultural dirigisme and any neat fit between Leichhardt and nation.

Amongst the politicking, there was some room for mutually beneficial transnational contacts between 'Leichhardt Friends' in East Germany and in Australia. For example, the East German Ludwig Leichhardt Jr acted as a mediator in the early 1960s between the Leichhardt family and the Public Library of South Australia regarding the publication of a facsimile of Leichhardt's (1845) Journal of an Overland expedition in Australia. He also assisted Aurousseau in the latter's three edited volumes of Leichhardt's letters. ${ }^{16}$ In the 1970s, Aurousseau would review Haufe's Leichhardt biography in The Australian Geographer. Yet, his review also indicates the limits to the transnational affinities that East German and Australian Leichhardt enthusiasts might have felt during this era. On the one hand, Aurousseau thought that Haufe's biography might do some good by popularizing the explorer in his homeland; however, he was highly critical of what he labelled the 'Marxist' interpretation of events, an interpretation that the state-owned Verlag der Nation had insisted that Haufe stress for domestic reasons (Aurousseau 1974, 471). ${ }^{17}$ In an era when Aurousseau's own volumes of Leichhardt's letters were seeking to disentangle the 'stranger' from his ideological denigration within Australia, he was no doubt especially sensitive to any other type of ideologization (Aurousseau 1968). Crucially, Aurousseau was also extremely critical of what he calls the 'unjust' way the biography portrayed settler Australia's policy of 'Ausrottung' (extermination) towards Indigenous people $(1974,472)$. Leichhardt's putatively favourable attitude towards Indigenous people was something that the state publisher wanted stressed for domestic 
reasons, since it could make him more of a 'socialist'. The biography's cover prominently depicts an Indigenous man sympathetically gazing at the East German reader, also suggesting the connection. This dispute about Leichhardt and about the treatment of Indigenous people during the colonial era underlines Rothberg's point that '[a]lthough it is difficult to grasp today [...] communism provided one of the discursive spheres $[\ldots]$ in which the articulation of genocide and colonialism could first be attempted - and this long before the intellectual vogue for [... ] postcolonial studies' $(2009,118)$. In Australia, the question would only be significantly aired in the following decades as historians began to concern themselves with what W.E.H. Stanner referred to in his (1968) Boyer lecture as the 'great Australian silence'. The German-Australian constellation became a sensitive one in this context. The Aboriginal activist Foley, who was involved in transnational networks between Australia and (West) Germany in the late 1970s and 1980s, has suggested that the Australian government was especially anxious that the comparison not be drawn between the Holocaust and treatment of Indigenous peoples, and was therefore very sensitive to the way that Indigenous issues were canvassed in Germany (2012). This aspect was to feature in a strikingly 'absent present' way during East German/Australian Leichhardt memorialization in 1988.

\section{8: The communist 'celebration of a nation'}

In the 25 years between the 1963 sesquicentennial and Leichhardt's 175th birthday during Australia's Bicentennial year much had changed in Australian-East German relations, as well as in the recuperation of Leichhardt in both Germany and Australia. In Australia, Aurousseau's and Elsie M. Webster's publications went some way to re-establishing Leichhardt's tarnished reputation (Aurousseau 1968; Webster 1980). The policy of multiculturalism and the approaching Bicentennial of Australia in 1988 quickened interest in Australia's non-English settler past (Hutchinson 1992). This provided impetus for the recovery of figures like Leichhardt, who now represented 'a non-British migrant identity that could be embraced by an increasingly multicultural nation' (Nicholls 2012, 161). It is symbolic that in Brisbane a plaque commemorating Leichhardt which had been languishing in storage since the early 1970 s - effectively as unclaimed scrap metal-was now reinstated on a prominent new building (Courier Mail 1988). Leichhardt was also treated to a new, recuperative biography by Roderick (1988). Concurrent with the establishment of diplomatic ties with West Germany in late 1972, the GDR had sought formal relations with other parts of the non-socialist world, including Australia, where an embassy was opened in 1973 (Monteath 2008). This period coincided with the belated publication of Haufe's Leichhardt biography, which not only promoted interest in the explorer in East Germany, but also now began to be deployed in the international diplomatic setting. ${ }^{18} 1988$ saw concerted new efforts to use Leichhardt as what Joachim Elm, the East German ambassador in Australia, called an 'Integrationspersönlichkeit' (integrating character) (Elm, quoted in Laurenz 2004a). Here, Elm echoed in a curious way remarks made in February 1933 by Australia's then Resident Minister in London and one of Australia's voices for appeasement of Germany, Stanley Bruce, when Bruce met the German Reichspräsident, Paul von Hindenburg. At that time, Bruce had also called up Leichhardt as a figure of integration between Australia and Germany (Bruce, quoted in Wagner 1936).

Four years prior to the 1988 'double anniversary', the East German communist party began to ponder how it could make 'the Leichhardt legacy much more useful to the GDR'. The guiding motivation here was that the GDR was interested in 'continuing to develop a 
relationship of peaceful coexistence' with Australia. ${ }^{19}$ Although the GDR maintained close contacts with Australia's socialist parties, it was clear-eyed about their ability to achieve socialist revolution. ${ }^{20}$ More pragmatically, it recognized that Australia's Labour party government was interested 'in the development of relations especially in trade and commerce'. ${ }^{21}$ This might be valuable at a time when the East German State was in a parlous economic condition, and very much interested in sources of hard currency from the non-socialist world. Such was the economic background to the gift of the bust in 1988, which alone cost 15,000 East German Marks, not counting freight costs via Warsaw and Belgrade to Canberra, or the cost of the other related Leichhardt commemoration activities that year. There was also a public relations benefit, if only the State was well-enough prepared. The party knew that the 'double anniversary' would awaken Australian interest in Leichhardt and that Australia would likely endeavour to invite East German Leichhardt family members and antiquarian enthusiasts to participate in commemorative activities. The Party recognized that it needed not only to be able to accommodate such requests, but that it should also approach the anniversary proactively to seek kudos in the non-Socialist world, thereby further assuaging ongoing anxieties. Whatever it might have said publicly, the GDR did not approach 'Leichhardt' here as a historical figure, but rather as an opportunity 'to advertise in Australia the GDR's current achievements'. A preliminary prong in the attack was promoting the study and admiration of Leichhardt in the GDR via a newly constituted 'Leichhardt-Komitee' and a Leichhardt museum in Trebatsch. These activities would culminate in an international conference in October in nearby Beeskow concerning the exploration of Australia 'with particular reference to Ludwig Leichhardt and other German scientists'. A Leichhardt gift - the State was already contemplating giving a sculpture to the Sydney municipality of Leichhardt - would be the second prong; it would be combined with 'an exhibition about the GDR and how Leichhardt's legacy is being cultivated in our Republic'. Tied up with this, however, was the tricky question of the Bicentennial; the State therefore began to prepare itself for the question of whether and how it should mark the 200th anniversary of the founding of the British colony, and the beginning of what Haufe's official biography had called the 'extermination' of Indigenous people. ${ }^{22}$

The GDR was therefore by no means unprepared when, during a short Australian visit by Gerald Götting (Deputy President of the State Council) in late 1987, the Commonwealth government expressed the view that a 200th anniversary present from the GDR would 'be welcomed'. It was Götting who took the initiative and proposed a bust of Leichhardt, a suggestion that met with swift approval from the Australian side. ${ }^{23}$ Despite political differences, East German participation via a Bicentennial gift was at some level a formal necessity; it would have been inconsistent to maintain diplomatic relations with East Germany and not to participate in the rite and economy of the political gift. Australia also had a material interest in soliciting the gift. As Monteath (2008) has shown, the Australian government had long been interested in expanding trade with the GDR, and this was a factor behind the official recognition of the GDR in 1972. The mutual desire to develop trade may not have ever have paid great dividends, but it did not prevent significant effort being put to that end, including during the 1980s. But an East German gift served other interests too. As Hutchinson has identified, the Australian government's motives in relation to the Bicentenary included a desire to make a grand statement in the international forum about its status as a nation; it vented the 'status anxieties' of a new nation $(1992,8)$. International participation in the Bicentenary was hence crucial. The Labour government was keen to stress the multiethnic character of the nation, as symbolized by the entry into Sydney Harbour of the Tall Ships of different countries, 
representing the different 'waves' of migration in the country's history. Soliciting a gift that highlighted German contributions to the nation's history would also accent the 'multiethnic' message. The East German bust-gift, which took its place in the new Parliament House amongst articles given by 30 countries - but no other busts - would contribute to the Bicentennial 'party' and augment Australia's international recognition, assuaging some of the 'status anxieties', in however a small way. ${ }^{24}$ Yet, Germany was something of a risk in 1988, given the reality of transnational 'multidirectional memory' (Michael Rothberg) that sought a parallel between the treatment of Indigenous people and the Holocaust. As Phillip Morrisey, coordinator of Aboriginal and Torres Strait Islander programmes for the Bicentenary Authority put it at the time: 'There is an analogy people sometimes use that asking Aboriginal people to celebrate the Bicentenary is like asking a Jewish person to celebrate the Third Reich' (Morrisey 1988, 26) This keyed in with a significant problem for the Bicentenary, prominent Indigenous opposition which stood to undermine the goal of international recognition. Here, Indigenous activists were prepared to and did use what Hutchinson calls 'a new transnational politics' to advance their cause in the Bicentennial year $(1992,22)$. Strikingly, East Germany would be one front for their agitation.

\section{No fixed address}

The East German State used the opportunity of the 1988 bust-gift to foster relations with Australia that might redound in quickening economic ties and an influx of hard currency, as well as to seek international kudos through proselytizing about the GDR's contributions to Leichhardt scholarship. It also used the gift to make statements about its policies of peaceful coexistence and opposition to nuclear warheads. ${ }^{25}$ The East German ambassador Joachim Elm's report back to East Berlin was largely positive about the returns on the Leichhardt investment, and the State file about the bust closed with a positive note. However, there were two catches to the State's strategy. First, as with the 1963 sesquicentennial, the East German State could not fully claim Leichhardt for itself; the West German State's rival national claim niggled away at ambassador Elm. Second, the State had to negotiate the issue of Indigenous Australian sentiments in 1988.

The East German State was anxious that the Leichhardt anniversary be used to attract attention towards itself, rather than its larger West German neighbour. However, control of the 'unstable' Leichhardt legacy again proved elusive in the transnational setting. It was not that there were two competing Leichhardt busts presented in 1988, one from East and one from West Germany that would have been too uncanny. (West Germany's Bicentennial gift to Australia was rather a functional dinner service for use in the Presiding Officers' suite at Parliament House [Jones, Haynes, and Barron 1993, 80].) Still, in his report, Elm expressed concern about how West German scholars were beginning to work on Leichhardt, and how the Federal Republic of Germany was also attempting to functionalize the memory of Leichhardt via a 'Ludwig Leichhardt Memorial Fellowship' and its own 'Leichhardt Society' in Australia. He recognized that West Germany had stolen the march on East Germany in terms of fostering Leichhardt scholarship; a UNSWhosted conference took place in Sydney in March, ahead of the East German conference in October, and it featured both West German scholars as well as Australian scholars 'with close West German contacts'. The chief drawcard at the UNSW conference might have been the East German Doppelganger Ludwig Leichhardt Jr, but his involvement seems to have been equivocal. Elm reported positively on Ludwig Jr's involvement in the parallel 
activities at the Leichhardt Town Hall: Ludwig Jr had used the opportunity 'to portray our Republic as a State that cultivates humanist traditions'. ${ }^{26}$ However, Leichhardt Jr has stated that he ignored the official script; 'I just said what I thought' (Leichhardt, quoted in Laurenz 2004b). ${ }^{27}$ Leichhardt Jr clearly enjoyed his time as keynote at the UNSW conference, and spent much of his time travelling in Australia with the convenor, Jürgen Tampke (Laurenz 2004a). In general, Elm was concerned about whether East Germany could keep up with West Germany in terms of reaping the international Leichhardt dividend. In this setting, he pondered what else the GDR should do: should it, for example, employ Ludwig Jr - an engineer - full time as a Leichhardt researcher, tying him closer to the State. ${ }^{28}$

The second catch was that the East German State was well and truly aware that members of Australia's Indigenous community, whom it regarded as potential political allies in the international advance of socialism, were opposed to the Bicentennial. ${ }^{29}$ It took fancy footwork to navigate this. The State could partly seek to avoid criticism by putting the emphasis during the 'double' anniversary on the Leichhardtian half. It had always been important to the East German State to suggest that Leichhardt had not been a "pacesetter for colonial exploitation in the service of imperialist powers' (Winz 1974, see also Hurley 2013). ${ }^{30}$ As we have seen, Haufe had referred to the 'white settlers' policy of extermination' in his official Leichhardt biography; he also portrayed Leichhardt by contrast as a good German who maintained relatively good relationships with Indigenous people. ${ }^{31}$ The East German 1988 conference carefully profiled Indigenous Australia and its 'changing image'. ${ }^{32}$ The organizers took pains to present Indigenous art from the Leipzig ethnological museum, and even included a demonstration by the 'Berlin-Marzahn boomerang group'. Admittedly, none of these activities involved actual Indigenous people. However, earlier in the Bicentennial year and somewhat incredibly, a different arm of the East German State paid respect to Australian Indigenous survival and protest in quite an unequivocal way. The Aboriginal political rock band No Fixed Address was invited to perform in February at East Berlin's Festival des politischen Liedes (Festival of Political Song), an important annual fixture in the East German musical calendar. The group used those 'new transnational politics' to tell a different story than the official State gift about Australia and European settlement. It is not yet clear here whether the East German state wished to appease Australia's Indigenous community in advance of its Bicentennial bust-gift - whether it was pursuing a complicated double politics - or whether the different arms of the State were simply disarticulated. On the other hand, neither is the Australian Government's involvement in No Fixed Address's East Berlin performance entirely clear. The Australian Government's conception of the Bicentennial 'was one that included, or desperately sought to include, Australia's Aboriginal people' (Bennett 1992, xviii). The Bicentenary Authority duly applied a policy of 'tactical pluralism' (Cochrane and Goodman 1992, 182). Whilst some Aboriginal groups were resolutely opposed to the Bicentennial celebrations and to 'blood money', there were some who maintained opposition as well as drawing on Bicentenary funds to mark their 'survival' - an enduring theme in No Fixed Address' music (Morrisey 1988). ${ }^{33}$ Notwithstanding the remaining questions, it is evident that the East German State played a thoroughly ambiguous, unsettled role in celebrating the Bicentennial and in fostering Indigenous protest to it. It facilitated the voice of transnational protest and paid respect to contemporary Indigenous survival. It also approached the Bicentennial via the figure of the 'good' Leichhardt, who could at least potentially be viewed as being at some order of remove from the British colonial project. However, the GDR knew that its bust-gift was helping the Commonwealth to celebrate the 'settlement of the continent by Europeans'. 
It did so in order to service its need for hard currency and to assuage two sets of 'status anxieties', its own and Australia's. ${ }^{34}$

\section{Conclusion}

In our joint essay, Schlunke asked how 'we might best deal with the contemporary assemblage of popular knowledge, material memory and an expanded historical record' that centres around Leichhardt. We began to look at the work that various Leichhardt biographies and fictional reworkings have performed, and set as a task for the future an examination of the 'eruption of material affects in the guise of specimens and memorials, emotional geographies that connect continents but also disappear' (Hurley and Schlunke 2013, 537, 542). Leichhardt's communist-era bust is one such thing. It points to some of the force that the past can have in the present, and how that force can be distributed in ways that both conform to and exceed national narratives.

Leichhardt's severed head poses insistent questions about how his missing body has been filled with meaning. The East German State literally reconstituted Leichhardt as a certain character 'type': a victim of classed society, a humanist scientist who was concerned with the betterment of mankind, a 'good' German who was well disposed to Indigenous people. In the process, the State filled an absence with the image of a real present-day East German, Ludwig Jr, who was, fittingly, an engineer when not engaged in Leichhardt research. The East German State was clear about using Leichhardt for a present-day political purpose. This sharpens our mind about the Australian side, since a gift is always part of an exchange. We should remind ourselves why the Commonwealth sought a Bicentennial gift from the East German state. Such an enquiry prompts us to ask what ideological work Leichhardt did within narratives of Australia at this time, something which I have begun to examine here, but which still calls for more research. To what extent was the newly discovered Australian Leichhardt shared - entangled with the East German state? Where did the two Leichhardts meet in a Cold War world that is still remembered in starkly polarized terms? Where did the two Leichhardts diverge?

A related question that Leichhardt's bust casts up here is whether he can ever be entirely contained by a single national narrative. The East German State tried to put him to service, but he evaded that at different times, either because some cadres did not regard him as socialist enough, or because he was folded into West Germany's competing national narrative. Especially when Leichhardt travelled beyond the GDR, he slipped beyond control, coming to life in the spaces created, when, say, Aurousseau found a positive side to Haufe's biography, or when Leichhardt Jr and Tampke travelled the country together. Finally, the body-less bust and its story prompt us to ponder what got uncomfortably elided in the mutually reconstitutive effort to mark him during the Bicentennial. In 1988, the East German State both emphasized and disavowed Indigenous Australia's claims through the parallel Festival of Political Song and the commemoration of Leichhardt. This disconcerting 'present absence' amplifies the Bicentennial's own ambiguous engagement with Indigenous Australia, but it also underlines questions about how the stranger Leichhardt might have been invested in dominant land politics of the colonial era, but also had interactions with Indigenous people that were somehow different, how he was both in and out of place. He therefore can bring into a transnational dimension the uncannily provocative role that Gelder and Jacobs regard Indigenous culture playing in Australian national discourse. Leichhardt's little bust, at rest in Trebtasch and in Canberra, can do that too. 


\section{Notes}

1. The bust was recently put back on display after a request from the German ambassador and Senator Susan Boyce. Prior to that, it had been in storage for over 10 years, having last been displayed in a short-term exhibition at Parliament House entitled 'Portraits in Stone' (Pollock 2013).

2. On the nineteenth-century German history of busts and death masks revering great minds, see, e.g., Benkard (1927, 26ff.).

3. On the prominence of busts in the GDR aesthetic, see also the recent 'Fokus DDR' exhibition at the Deutsches Historisches Museum, held between 7 June and 25 November 2012. A panorama shows a selection of the busts displayed in that exhibition: http://www.dhm.de/ausstellungen/ fokus-ddr/flashpano/start_en.html. Thanks to Lindsay Barrett for alerting me to this.

4. The 1988 bust is but one of a long line of Leichhardt bust-gifts and other visual representations of the explorer. Many of these are copies of absent, long-lost, disappeared or destroyed originals. The earliest bust is Charles Abraham's plaster bust of 1846, a copy of which is now in the National Portrait Gallery. For a long time, however, it was considered that 'no known copy survive[d] in Australia' (Aurousseau 1974, 472). Another bust was made from memory in 1853 by the Parisian sculptor, Verreaux (probably a relative of Jules-Pierre Verreaux, who was sent to Australia by the French Museum d'histoire naturelle, and who knew Leichhardt). It was given by the Royal Geographical Society of London to the Berlin Gesellschaft für Erdkunde later in the decade (Aurousseau 1974, 472, see also Haufe 1963, 261). A plaster copy of that bust was sent to the Paris exhibition in 1885. Another copy was purchased by Prussia through Minister Friedrich von Raumer (Haufe 1963, 263). Various representations of Leichhardt were destroyed during WWII. These include not only the Verreaux bust in Berlin, but also a portrait of Leichhardt, painted by his brother-in-law F.A. Schmalfuss from memory after his disappearance. The explorer's grand niece, the painter Elisabeth Wolf, copied this destroyed painting from her own memory after the war (Haufe 1963, table 44). On visual representations of Leichhardt, and the way many of them are copies of copies, see Gannon 2013.

5. '[W]enn die Nationalsozialisten den Australienforscher geehrt hatten, wie konnte man ihn dann in der "antifaschistischen" DDR ehren?'

6. For example, two editions of Leichhardt's journal of his first expedition to Port Essington were published in the then East German Brockhaus-Verlag (Damm 1951; Helbig and Schlieben 1959). Excerpts from some of Leichhardt's letters were also published in Scurla's (1959) Entdeckungen auf vier Kontinenten.

7. 'die hohe Entwicklung der Menschheit'.

8. 'gründliche Einschätzung der Persönlichkeit Leichhardts'.

9. This was not the only problem; the council was also concerned that such a move might reawaken latent Nazi sympathies in the area (Marx 2003, 47).

10. For an account of the genesis and reception of the biography, see Hurley (2013).

11. This seems to be the intention of the President of the East German Geographical Society, Johannes E. Gellert (Marx 2003, 39).

12. Publication was held up for many years, much to Haufe's disappointment. He lobbied the stateowned press assiduously. Ultimately, his lobbying revolved around the external kudos that the biography might engender both from West German experts, and, as the possibility of the GDR establishing diplomatic contact with Australia opened up, in Australia too. See Hurley (2013).

13. 'Meine Vorstellungen wurdqbei weitem uebertroffen [...] Ich werde immer gern zu ihnen kommen in die DDR'.

14. Göttingen had links with Cambridge and Oxford universities and was a key site in transnational ties between Germany and England, and her colonies (Tampke 2006, 1, 21-22).

15. One of Haufe's earliest articles about Leichhardt was for the DDR Revue, a publication for the English-speaking world (Letter Haufe to Brandl, 8 September 1963. Bundesarchiv Stiftung Archiv der Parteien und Massenorganisationen der DDR, file DY17 2355).

16. See Pol. Archiv des Auswärtigen Amts, MfAA ZR 1364/89.

17. On the publisher's manipulation of Haufe's text, see Hurley (2013).

18. See, e.g., Leichhardt, quoted in Warren (1988).

19. 'das Leichhardt-Erbe für die DDR stärker nutzbar'/'Weiterentwicklung von Beziehungen der friedlichen Koexistenz', quoted in R. Zipfel, Vermerk, 20 February 1986, Bundesarchiv Stiftung Archiv der Parteien und Massenorganisationen der DDR, DY 30; 12987, 2, 3. 
20. See Monteath (2008) and also 'Informationsmaterial ueber die sozialistische Partei Australiens', April 1987, Bundesarchiv Stiftung Archiv der Parteien und Massenorganisationen der DDR, DY 30; 12987, $2-3$.

21. 'an der Entwicklung der Beziehungen, besonders auf wirtschaftlichen Gebiet', 'Informationsmaterial', April 1987, Bundesarchiv Stiftung Archiv der Parteien und Massenorganisationen der DDR, DY 30; 12987, 2.

22. 'die aktuellen Errungenschaften der DDR in Australien stärker bekanntzumachen'/'unter besonderer Würdigung Ludwig Leichhardts und weiterer deutscher Wissenschaftler'/'eine Ausstellung über die DDR und die Pflege des Leichhardt-Erbes in unserer Republik'. All quotes from R. Zipfel, Vermerk, 20 February 1986, Bundesarchiv Stiftung Archiv der Parteien und Massenorganisationen der DDR, DY 30; 12987, $2-4$.

23. 'begrüßt werden würde'. Letter Götting to Honecker, 14 September 1987, Pol. Arch des Auswaertigen Amts, MfAA ZR 1364/89.

24. For a description of Bicentennial gifts received from other countries, see Jones, Haynes, and Barron (1993, 23-25, 80-81).

25. See, e.g., Letter Sindermann to Sibraa n.d., Pol. Arch des Auswaertigen Amts, MfAA ZR $1364 / 89$.

26. 'australische Wissenschaftler mit engen BRD-Verbindungen'/'unsere Republik als Staat, der humanistische Traditionen pflegt, darzustellen'. Letter Elm to various addressees, 7 April 1988, Pol. Arch des Auswaertigen Amts, MfAA ZR 1364/89.

27. 'Ich habe das gesagt, was ich dachte'.

28. Letter Elm to various addressees, 7 April 1988, Pol. Arch des Auswaertigen Amts, MfAA ZR $1364 / 89$.

29. See, e.g., Zur Vorlage für das Sekretariat des ZK der SED 'Massnahmen zur 200Jahrfeier Australiens 1988', 5 January 1988. Pol. Arch des Auswaertigen Amts, MfAA ZR $1364 / 89$.

30. 'Schrittmacher einer kolonialen Ausbeutung im Dienste imperialistischer Mächte'.

31. 'Ausrottungspolitik der weißen Siedler' (Haufe 1972, 103). Cf. M. Boettcher. 'Aktennotiz', 16 August 1971. Bundesarchiv Stiftung Archiv der Parteien und Massenorganisationen der DDR, DY17 2355.

32. 'sich wandelndes Bild'. From the title the East German anthropologist Frederick G.G. Rose's paper at the conference.

33. On No Fixed Address's music and politics, see, e.g., Castles (1998).

34. 'Besiedlung des Kontinentes durch die Europäer'. Zur Vorlage für das Sekretariat des ZK der SED 'Massnahmen zur 200-Jahrfeier Australiens 1988', 5 January 1988. Pol. Arch des Auswaertigen Amts, MfAA ZR 1364/89.

Notes on contributor Andrew Wright Hurley is a Senior Lecturer in the International Studies programme at UTS. He is the author The Return of Jazz: Joachim Ernst Berendt and West German Cultural Change (Berghahn Books, 2009) and Into the Groove: Popular Music and Contemporary German Fiction (Camden House, forthcoming). He has published widely on German cultural history and on German-Australian topics.

\section{References}

Aurousseau, Marcel. 1964. "Sesqui-Centenary of the Birth of Ludwig Leichhardt." The Australian Geographer 9 (3): 176.

Aurousseau, Marcel, ed. 1968. The Letters of F.W. Leichhardt. Vols. 1-3. London: Cambridge University Press.

Aurousseau, Marcel. 1974. "Review of Haufe, Entdeckungsreisen." The Australian Geographer 12 (5): $471-472$.

Benkard, Ernst. 1927. "The History of the Death Mask." In Undying Faces: A Collection of Death Masks, edited by Ernst Benkard and Margaret Green. New York: W.W. Norton. Accessed November 12, 2013. http://www.undyingfaces.com/info/death-mask-history/

Bennett, Tony. 1992. "Introduction: National Times." In Celebrating the Nation: A Critical Study of Australia's Bicentenary, edited by Tony Bennett, Pat Buckridge, David Carter, and Colin Mercer, xiii-xviii. St Leonards: Allen \& Unwin.

Brunner, Dieter. 2005. "Die Büste nach der Büste. Ein Forschungs- und Ausstellungsprojekt.” In Die obere Hälfte. Die Büste seit Auguste Rodin, edited by Dieter Brunner, Marc Gundel, Achim Sommer, and Toni Stoos, 8-9. Bönnigheim: Edition Braus im Wachter Verlag. 
Castles, John. 1998. “Tjungaringanyi: Aboriginal Rock (1971-91).” In Sound Alliances: Indigenous Peoples, Cultural Politics and Popular Music in the Pacific, edited by Philip Haywood, 11-25. London: Cassell.

Caute, David. 2003. The Dancer Defects: The Struggle for Cultural Supremacy during the Cold War. Oxford: Oxford University Press.

Chisholm, Alec. 1941. Strange New World. Sydney: Angus and Robertson.

Clark, Katerina. [2001] 2012. "Socialist Realism in Soviet Literature." In From Symbolism to Socialist Realism: A Reader, edited by Irene Maing-Delic, 419-432. Boston, MA: Academic Studies Press.

Cochrane, Peter, and David Goodman. 1992. "The Great Australian Journey: Cultural Logic and Nationalism in the Postmodern Era." In Celebrating the Nation: A Critical Study of Australia's Bicentenary, edited by Tony Bennett, Pat Buckridge, David Carter, and Colin Mercer, 175-190. St Leonards: Allen \& Unwin.

Corleis, Jürgen. 1988. "Australien ehrt seinen berühmtesten Deutschen.” Lausitzer Rundschau, Cottbus, April 14.

Courier Mail. 1988. "Brisbane. Historic Plaque Makes a Comeback." September 8.

Damm, Hans, ed. 1951. Ins Innere Australiens: Die erste Durchquerung von Brisbane zur Nordküste. Leipzig: Brockhaus Verlag.

Davison, Graeme. 1988. "The Use and Abuse of Australian History." In Making the Bicentenary, Australian Historical Studies, edited by Susan Jason and Stuart Macintyre, 23, 55-76. Parkville: Faculty of Arts, University of Melbourne.

Donner, Helmut. 1998. "Das Leichhardt-Bild des 20. Jahrhunderts: Ein Literaturbericht.” In Ludwig Leichhardt, edited by Rolf Striegler, Steffen Krestin, Konrad Grunert, and Wolf-Dieter Heym, 34-47. Cottbus: Naturwissenschaftlicher Verein der Niederlausitz e.V.

Fischer, Gerhard. 2009. "Debating the 'German Presence' in Australia. Notes on Research and Research Desiderata." In Migration and Cultural Contact: Germany and Australia, edited by Andrea Bandhauer and Maria Veber, 131-151. Sydney: Sydney University Press.

Foley, Gary. 2012. "Interview with the Author." Sydney, March 30.

Freud, Sigmund. [1919] 1999. "The "Uncanny'." Edited and translated by James Strachey, with Anna Freud, Alix Strachey and Alan Tyson, The Standard Edition of the Complete Psychological Works of Sigmund Freud, Volume XVII (1917-1919): An Infantile Neurosis and Other Works, 217-256. London: Vintage.

Gannon, Bill. 2013. "Portraying Leichhardt." Paper presented at Leichhardt's Legacies conference, UTS.

Gelder, Ken, and Jane M. Jacobs. 1998. Uncanny Australia: Sacredness and Identity in a Postcolonial Nation. Melbourne: Melbourne University Press.

Granata, Cora. 2009. "The Cold War Politics of Cultural Minorities: Jews and Sorbs in the German Democratic Republic, 1976-1989." German History 27 (1): 60-83.

Groys, Boris. [1992] 2012. "The Typology of the Nonexistent." In From Symbolism to Socialist Realism: A Reader, edited by Irene Maing-Delic, 433-439. Boston, MA: Academic Studies Press.

Haufe, Heinz. 1963. "Zum 150. Geburtstag Ludwig Leichhardts." Petermanns Geographische Mitteilungen 4: 259-263.

Haufe, Heinz. 1972. Entdeckungsreisen in Australien. Ludwig Leichhardt, ein deutsches Forscherschicksal. Berlin: Verlag der Nation.

Helbig, Karl, and Hans Joachim Schlieben, eds. 1959. Schicksal im australischen Busch. Vorstoß in das Herz eines Kontinents. Leipzig: Brockhaus Verlag.

Hurley, Andrew. 2013. "Son of the Soil, Proto-Socialist or Free Spirit? Heinz Haufe's Entdeckungsreisen in Australien and the Rehabilitation of Ludwig Leichhardt in East Germany." Limbus 6: 209-224.

Hurley, Andrew, and Katrina Schlunke. 2013. "Leichhardt after Leichhardt.” Journal of Australian Studies 37 (4): 537-543.

Hutchinson, John. 1992. "State Festivals, Foundation Myths and Cultural Politics in Immigrant Nations." In Celebrating the Nation: A Critical Study of Australia's Bicentenary, edited by Tony Bennett, Pat Buckridge, David Carter, and Colin Mercer, 3-25. St Leonards: Allen \& Unwin.

Jones, Michael, Peter Haynes, and Sonia Barron, eds. 1993. Expressing Australia: Art in Parliament House. Canberra: Canberra Press. 
Kohl, Jeanette. 2005. "Die obere Hälfte. Ansätze zu einer Phänomenologie der vor-modernen Büste." In Die obere Hälfte. Die Büste seit Auguste Rodin, edited by Dieter Brunner, Marc Gundel, Achim Sommer, and Toni Stoos, 11-22. Bönnigheim: Edition Braus im Wachter Verlag.

Laurenz, Konstantin. 2004a. "Wie Leichhardts Büste nach Canberra kam." Cottbusser Rundschau, July 3 .

Laurenz, Konstantin. 2004b. "Ludwig Leichhardt sass Modell fuer Museumsbüste." Lausitzer Rundschau, September 16.

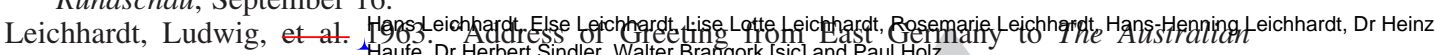

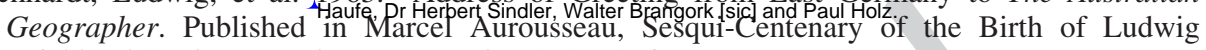
Leichhardt." The Australian Geographer 9 (3): 176.

Lewis, Darrell. 2013. Where is Dr Leichhardt? Clayton: Monash University.

Martin, Susan K. 2013. "Ludwig Leichhardt in der australischen Literatur." In Der Australienforscher Ludwig Leichhardt: Spuren eines Verschollenen, edited by Heike Hartmann, 119-128. Berlin: be.bra wissenschaft verlag.

Marx, Bernd. 2003. Ludwig Leichhardt - Sohn der Niederlausitz. Trebatsch: Gesellschaft Ludwig Leichhardt e.V.

Monteath, Peter. 2008. "The German Democratic Republic and Australia." Debatte: Journal of Contemporary Central and Eastern Europe 16 (2): 213-235.

Morrisey, Phillip. 1988. "The View from the Authority." In Aboriginal Perspectives of the Bicentenary: A Collection of Papers, 23-26. Canberra: ACT Schools Authority.

Nicholls, Angus. 2012. “'The Core of this Dark Continent'. Ludwig Leichhardt's Australian Explorations." In Transnational Networks: German Migrants in the British Empire, 1670-1914, edited by John R. Davis, Stefan Manz, and Margit Schulte Beerbühl, 141-162. Leiden: Brill.

Nicholls, Glenn. 2000. "Exploration and Immigration: How Intercultural Interpretations are Changing the History of Ludwig Leichhardt.” Journal of Intercultural Studies 21 (1): 25-37.

Pietzner-Clausen, Paul. 1940. Der Heimaterde entrissen. Lebensschicksale deutscher Männer. Berlin: Gutenberg.

Priessnitz, Horst. 1991. “The 'Vossification' of Ludwig Leichhardt.” In From Berlin to the Burdekin: The German Contribution to the Development of Australian Science, Exploration and the Arts, edited by David Walker, 196-217. Kensington: UNSW Press.

Roderick, Colin. 1988. Leichhardt the Dauntless Explorer. Sydney: Angus and Robertson.

Rothberg, Michael. 2009. Multidirectional Memory: Remembering the Holocaust in the Age of Decolonization. Stanford, CA: Stanford University Press.

Schlunke, Katrina. 2014. "Beyond Nation? Ludwig Leichhardt's Transnationalism." Coolabah (Journal of the Australian Studies Centre at Universitat de Barcelona) 13: 163-172.

Scurla, Herbert. 1959. Entdeckungen auf vier Kontinenten. Berlin: Verlag der Nation.

Stanner, W. E. H. 1968. After the Dreaming. Sydney: Australian Broadcasting.

Tampke, Juergen. 2006. The Germans in Australia. Melbourne: Cambridge University Press.

Thomas, Martin. September 2013. "Leichhardt on the Mind: The Manhunt Continues for the Prussian Enigma." Australian Book Review $354-21$.

Wagner, Paul. 1936. "Ludwig Leichhardt: Dem vergessenen deutschen Forscher zum Gedächtnis!" Tägliches Kreisblatt, Beeskow-Storkow, 5 September. Copy held at 'Ludwig Leichhardt' Kulturzentrum archive, Trebatsch.

Warren, Matthew. 1988. "Distant Nephew Restores Link with Missing Explorer." The Australian, April 11.

Webster, Elsie M. 1980. Whirlwinds in the Plain. Ludwig Leichhardt - Friends, Foes and History. Melbourne: Melbourne University Press.

Winz, Ulrich. 1974. "Review of Haufe." Entdeckungsreisen in Australien. Märkische Union, February 23 and March 2. 